\title{
A Conversion-Period Burial in an Ancient Landscape: A High-Status Female Grave near the Rollright Stones, Oxfordshire/Warwickshire
}

\author{
Helena Hamerow
}

In March 2015, a metal detector user uncovered several early medieval artefacts from land adjacent to the Rollright Stones, a major prehistoric complex that straddles the Oxfordshire-Warwickshire border (O.S. SP 2963 3089). He alerted the Portable Antiquities Scheme and the well-preserved burial of a female, aged around 25-35 years and aligned South-North, was subsequently excavated (Fig. 11.1). ${ }^{1}$ The grave-which was shallow, undisturbed (apart from a small area of disturbance near the skull caused by the detectorist) and produced no evidence for a coffin or other structures - contained a number of remarkable objects indicating a 7 th-century date for the burial. This was confirmed by two samples of bone taken for AMs radiocarbon dating, which produced a combined date of $622-65^{2}$ cal $A D$ at 68.2 per cent probability and 604-656 cal AD at 95.4 per cent probability (OxA-37509, OxA-37510). The burial lay some $50 \mathrm{~m}$ northeast of a standing stone presumed to be prehistoric in date, known locally as the 'King Stone'. ${ }^{2}$ This burial and its remarkable setting form a significant addition to the corpus of well-furnished female burials which are shedding new light on the role of women in Conversion-period England, about which Barbara Yorke has written so compellingly.

At the time of writing, conservation of the artefacts from the burial has not begun and the brief description of the main objects provided here must therefore be regarded as provisional. ${ }^{3}$ The first and most striking object to beidentified

1 The excavation was undertaken by Anni Byard, David Williams, and Ros Tyrrell, Finds Liaison Officers for Oxfordshire, Surrey and East Berkshire, and Buckinghamshire. I am grateful to David Haine, Charles Wood, the Oxfordshire Museums Service, and the Rollright Trust for providing access to the site and finds. The finds and archive are now housed in the Ashmolean Museum, Oxford. I am also grateful to George Lambrick for his comments on the text, and to Abi Tompkins for preparing Fig. 11.6

2 George Lambrick, The Rollright Stones. Megaliths, Monuments and Settlement in the Prehistoric Landscapes (London, 1988).

3 Descriptions of the objects are based on the Treasure Report issued by the British Museum (Treasure Number 2015T270). I am grateful to Dr Sue Brunning for permission to cite this report. The artefacts and archive are now held by the Ashmolean Museum, Oxford. 


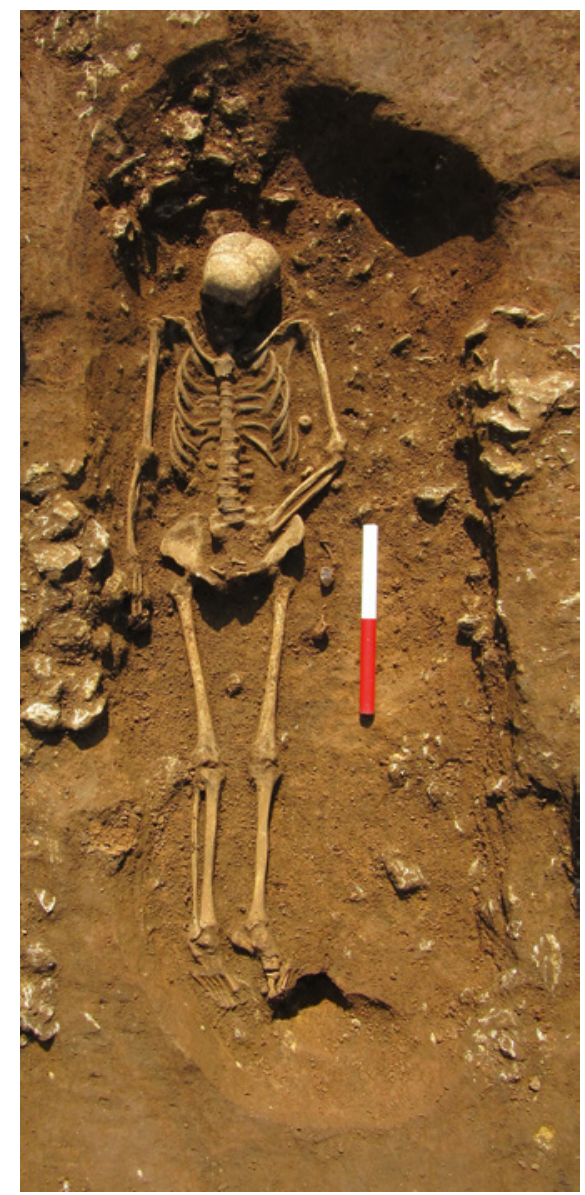

FIGURE 11.1

The Rollright Stones Anglo-Saxon burial (C) A. BYARD, PORTABLE ANTIQUitiES SCHEME

was a long-handled copper alloy skillet lying to the left of the head. A circular, embossed silver disc inlaid with a single garnet was probably originally set into the base of the skillet, and a silver sheet decorative mount with a crescentshaped plate is also likely also have been associated with it (Figs. 11.2 and 11.3). Such skillets - which are closely modelled on the Roman trulleum, used in handwashing rituals ${ }^{4}$ — are rare: only around seven other examples are known. ${ }^{5}$ The skillet appears to have been placed inside a lockable wooden casket, the copper alloy fittings of which-including a decorated lock plate and two

4 Anthea Harris and Martin Henig, "Hand-washing and Foot-washing, Sacred and Secular, in Late Antiquity and the Early Medieval Period," in Intersections: The Archaeology and History of Christianity in England, 400-1200: Papers in Honour of Martin Biddle and Birthe KjølbyeBiddle, ed. Martin Henig and Nigel Ramsay, BAR British Ser. 505 (Oxford 2010), pp. 25-38. I am grateful to Martin Henig for his observations on the Roman trulleum.

5 Helen Geake, "Medieval Britain and Ireland, 2005," Medieval Archaeology 50 (2006), 283-86. 


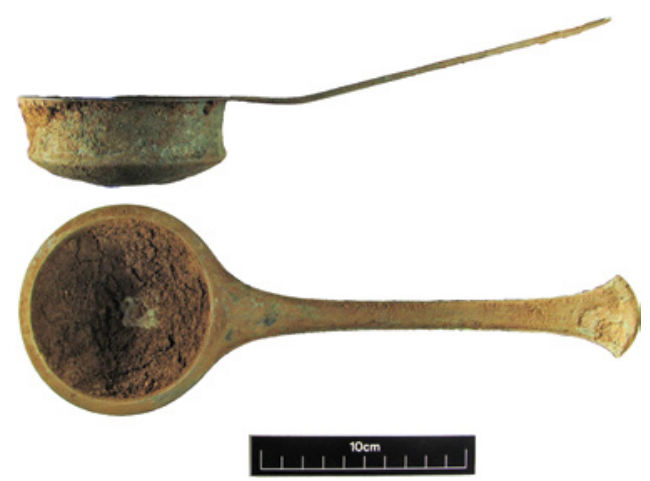

FIGURE 11.2 The skillet/trulleum

(C) A. ByARD, PORTABLE ANTiQuities SCHEME
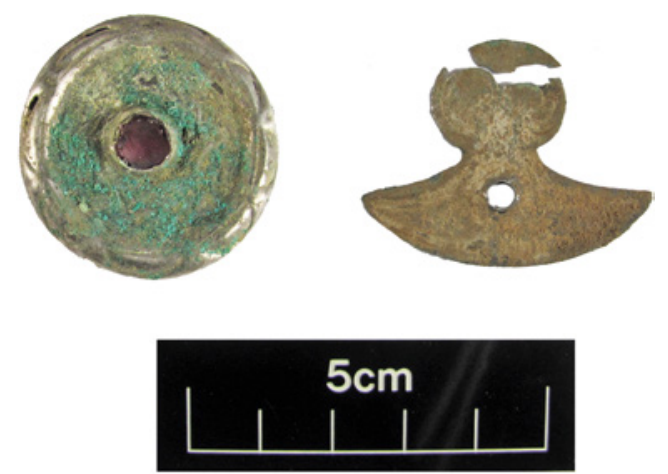

FIGURE 11.3 Silver mounts

(C) A. BYARD, PORTABLE ANTIQUities SCHEME

hinges with triangular plates, one of which has been repaired-survive (Fig. 11.4). Such boxes are found in well-furnished burials of the 7 th century and tend to be associated with females. ${ }^{6}$ A close parallel for the hinges and lockplate is provided by the casket found in the richly furnished 7 th-century female burial at Swallowcliffe Down in Wiltshire. ${ }^{7}$

6 Forty out of forty-three wooden boxes included in a recent survey of Anglo-Saxon grave goods were found in female graves. John Hines and Alex Bayliss, eds., Anglo-Saxon Graves and Grave Goods of the 6th and 7th Centuries AD: A Chronological Framework (London, 2013), pp. 227-29; see also Helen Geake, The Use of Grave-Goods in Conversion-Period England, c. 6oo-85o, BAR Brit. Ser. 261 (Oxford, 1997), pp. 82-83.

7 George Speake, A Saxon Bed Burial on Swallowcliffe Down (London, 1989), pp. 24-30. A deposit of small, spherical black seeds was found nearby and may have been associated with the box; although a sample was collected during the excavation, this could not be located at the time of writing (A. Byard, pers. comm.). 

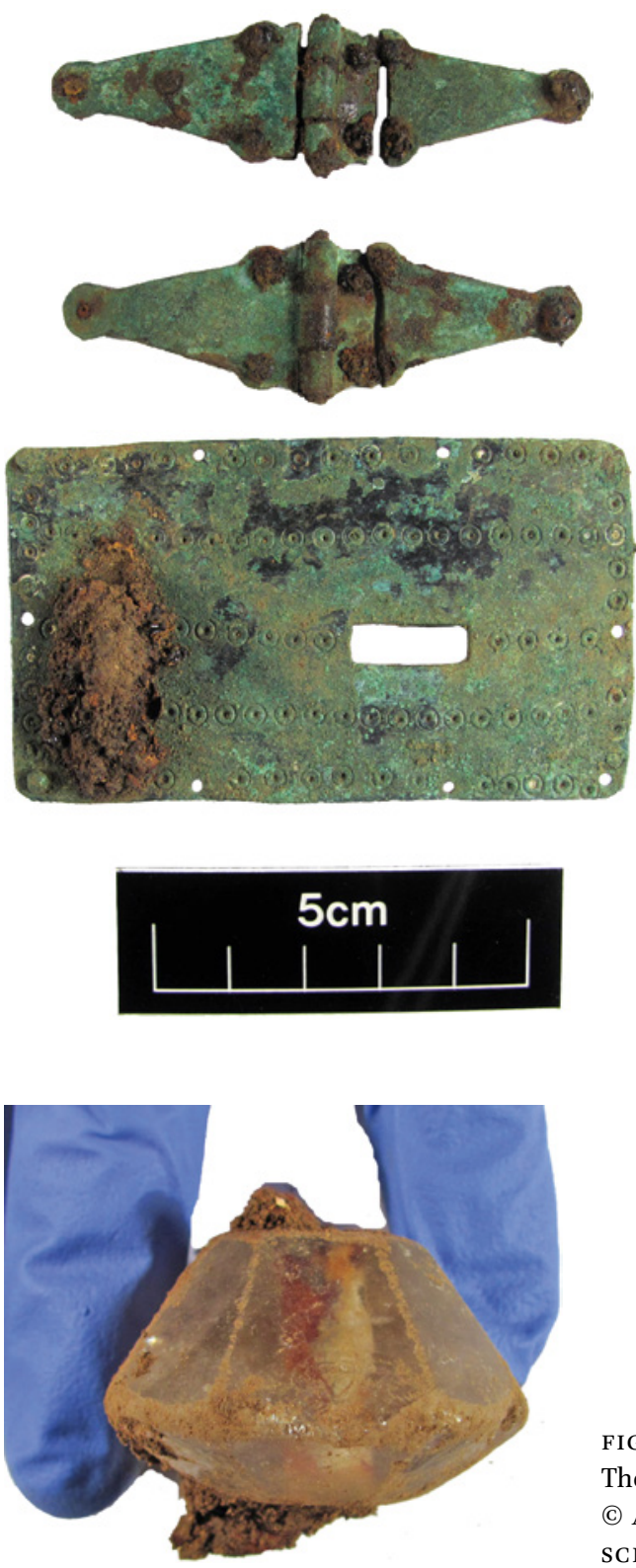

FIGURE 11.4

The box fittings

(C) A. BYARD, PORTABLE ANTIQUITIES SCHEME
FIGURE 11.5

The rock crystal pendant

(C) A. BYARD, PORTABLE ANTIQUities SCHEME

A large, biconical facetted rock crystal bead, still attached to the remains of a chain or chatelaine, lay at the left side of the body (Fig. 11.5). It had presumably been suspended from an organic belt, of which no trace survived. Crystal beads were a fairly standard part of the burial kit of high status Merovingian and Anglo-Saxon women of childbearing age and were a "conspicuous sign 
of wealth." ${ }^{8}$ The bead is visibly chipped and appears to have sustained some damage prior to burial; it is possible that it had previously been used as a spindlewhorl.

Two small, plain copper alloy pins with round shafts and globular heads, together with fine, figure-of-eight chain links found near the head, may derive from a linked pin set of the kind used to fasten veils or headdresses in the 7 th century, although this remains uncertain in advance of conservation. ${ }^{9} \mathrm{~A}$ single, large amber bead lay to the left of the ribs and a perforated antler disc was found lying beneath the ribs and partly beneath the spine, on the right hand side. Although these two objects lay some distance apart, it is possible that both were originally contained in an organic pouch.

The casket, linked pins, and skillet can all be relatively closely dated. As already noted, skillets are rare, but those that have been found in dateable contexts or with dateable decoration belong to the 7 th or possibly early 8th century. According to the most recent and comprehensive chronological and typological framework for Anglo-Saxon grave goods, linked pins date to between the second quarter and the end of the 7 th century, ${ }^{10}$ while boxes are found in graves of the late 6th and 7 th centuries. ${ }^{11}$ In light of the radiocarbon dates, it is unlikely that any of these objects was particularly old when buried.

A marked increase in the frequency of well-furnished female burials occurred in England around the second quarter of the 7 th century and burial wealth continued to be invested primarily in the graves of females until the practice of furnished burial came to an end around $700 .{ }^{12}$ Following a general decline in the provision of grave goods with both males and females in the later 6th century, and the glittering but short-lived phase of male 'princely' burials that lasted from around the 590 os to the 630s-of which Sutton Hoo Mound 1 is the richest and the Prittlewell chamber grave the earliest-mortuary display shifted decisively to the burials of females. Burials of males were thereafter much more likely to be sparsely furnished or unfurnished. Well-furnished female burials like the one at Rollright are thus a distinctive feature of the archaeology of 7 th-century England. The best known and most spectacular examples, such as the burials from Swallowcliffe Down (Wilts.), Roundway Down

$8 \quad$ Numerous parallels are cited in Genevra Kornbluth, "Merovingian Rock Crystal: Practical Tools And Status Markers," in Golden Middle Ages in Europe: New Research into EarlyMedievalCommunities and Identities, ed. Annemarieke Willemsen and Hanneke Kik (Turnhout, 2015), pp. 49-56.

$9 \quad$ Geake, The Use of Grave Goods, pp. 35-36.

10 Hines and Bayliss Type P12a: Hines and Bayliss, Anglo-Saxon Graves and Grave-Goods, pp. $225^{-26 .}$

11 Geake, The Use of Grave-Goods, pp. 81-82.

12 Hines and Bayliss, Anglo-Saxon Graves and Grave-Goods. 
(Wilts.) and Desborough (Northants), merely represent the richer end of a broad spectrum of ostentatiously furnished burials of females whose funerals offered their families the opportunity to engage in competitive display. ${ }^{13}$ While male 'princely' burials are regarded as signalling, in Tania Dickinson's words, "moments of specific political tension," I have argued elsewhere that the wellfurnished female burials that succeeded them were a means of conferring supernatural legitimacy and protection over their family's claims to land and resources. ${ }^{14}$ This is a possibility whose relevance in the context of the Rollright burial will become clear in the following discussion.

The Rollright burial displays several characteristics typical of female burials of this period. These include a marked shift in dress away from northern Germanic traditions that involved pairs of brooches, belt buckles and long strings of glass and amber beads, to dress accessories inspired by eastern Mediterranean and Frankish fashions, such as light necklets and pins used to fasten head coverings. ${ }^{15}$ This shift in dress style is now widely regarded as a means of constructing elite status and projecting authority, rather than signalling the adoption of Christianity per se. ${ }^{16}$ The 7 th century also saw an increasing use of containers, above all pouches and boxes, in which special objects were concealed. The objects they contained often display signs of wear and thus of extended biographies, appear to have denoted the status of a 'free' woman (such as spindlewhorls and shears), and/or had amuletic qualities. Indeed, objects whose function appears to have been amuletic - i.e. they were believed to have magical qualities that could prevent harm or bring good luck—generally occur with greater frequency in the 7 th century. Such items include the claws and teeth of certain animals, cowrie shells, and fossils, but also crosses and other items with explicitly religious connotations. ${ }^{17}$

13 Speake, Swallowcliffe Down; Sarah Semple and Howard Williams, "Excavations on Roundway Down," WANHM 94 (2001), 236-39; R.S. Baker, "On the Discovery of Anglo-Saxon Remains at Desborough, Northamptonshire," Archaeologia 45 (1880), 466-71.

14 Tania Dickinson, "What's New in Early Medieval Burial Archaeology?" EME 11:1 (2002), 71-87, at p. 85; Helena Hamerow, "Furnished Female Burial in Seventh-Century England: Gender and Sacral Authority in the Conversion Period," EME 24:4 (2016), 423-47.

15 Helen Geake, "Invisible Kingdoms: The Use of Grave-Goods in Seventh-Century England," ASSAH 10 (Oxford, 1999), 203-15.

16 West-East alignment of burials was already prevalent in early Anglo-Saxon England and should not be assumed to signal Christian belief at this early date (Nick Stoodley, The Spindle and the Spear. A Critical Enquiry into the Construction and Meaning of Gender in the Early Anglo-Saxon Burial Rite, BAR Brit. Ser. 288 (Oxford, 1999), pp. 63-66); conversely, South-North alignment of an isolated burial, as in the case of the Rollright burial, does not rule out the possibility that the family of the deceased woman regarded itself as Christian.

17 Hamerow, "Furnished Female Burial." What appears to be a dog's tooth was found in the area of the skull. There was no evidence to suggest it had been deliberately placed there, however, and it shows no signs of having been modified in any way. 
The burial of the woman found at Rollright mirrors these wider trends in several respects. The linked pin suite and facetted rock crystal bead suspended from a chatelaine reflect Mediterranean or Frankish influences, while single amber beads and antler discs are both categories of object that have been classed as 'amulets'. Rock crystal too was regarded as an inherently powerful material in the Roman and post-Roman worlds. ${ }^{18}$ The skillet - which had apparently been concealed inside the casket ${ }^{19}$ — should also be seen as an object with ritual, perhaps even religious, connotations. As already noted, such skillets are strikingly similar to the Roman trulleum, like those found at the Sacred Spring at Bath. ${ }^{20}$ In a Roman context, the trulleum was used in hand-washing rituals, notably prior to feasting. Contemporary depictions show it being held under the hands, to collect water poured from a ewer. Hand washing vessels have been found in Roman graves of high status and may have been used in funerary rituals, although ritual ablutions also appear 'in a specifically Christian context. ${ }^{21}$ It is worth noting in this context that an Anglo-Saxon skillet found at Shalfleet on the Isle of Wight, was decorated with a cruciform mount. ${ }^{22}$

The grave assemblage from Rollright thus reflects wider trends in mortuary practice across 7 th-century England. The placement of the burial in relation to the King Stone and its immediate surroundings is, however, particularly striking and merits detailed consideration. If ancestral burials were placed in the early medieval landscape as a means of constructing social and ideological messages ${ }^{23}$ what was the burial of this individual in this remarkable location intended to communicate?

18 Kornbluth, "Merovingian Rock Crystal"; Audrey Meaney, Anglo-Saxon Amulets and Curing Stones, BAR Brit, Ser. 96 (Oxford 1981), pp. 67-71, 139-42.

19 One of the burials at Desborough contained a copper alloy skillet which may also have been associated with a casket (as well as other items), as suggested by a single surviving triangular hinged fitting (Baker, "Anglo-Saxon Remains at Desborough").

$20 \quad$ B.W. Cunliffe, ed., The Temple of Sulis Minerva at Bath Vol. 2. The Finds from the Sacred Spring (Oxford 1988), pls. X-XVI. While Anglo-Saxon examples are rare, their distribution suggests an emphasis on Mercia and Wessex.

21 Harris and Henig, "Hand-washing and Foot-washing," pp. 28-30 and Fig. 2.

22 Geake "Medieval Britain and Ireland." Parallels may be drawn with Barbara Yorke's interpretation of the hanging bowl from a male burial near Winchester as having been used by a high-ranking family in formal, Roman-inspired hand-washing ceremonies associated with feasting (Barbara Yorke, "The Oliver's Battery Hanging-Bowl Burial from Winchester, and its Place in the Early History of Wessex," in Intersections, ed. Henig and Ramsay, pp. 77-86). If the garnet-inlaid silver mount can be shown to have been set into the base of the Rollright skillet, this would increase the likelihood that its use involved a clear liquid, i.e. water.

23 Sarah Semple and Howard Williams, "Landmarks for the Dead: Exploring AngloSaxon Mortuary Geographies," in The Material Culture of the Built Environment in the 


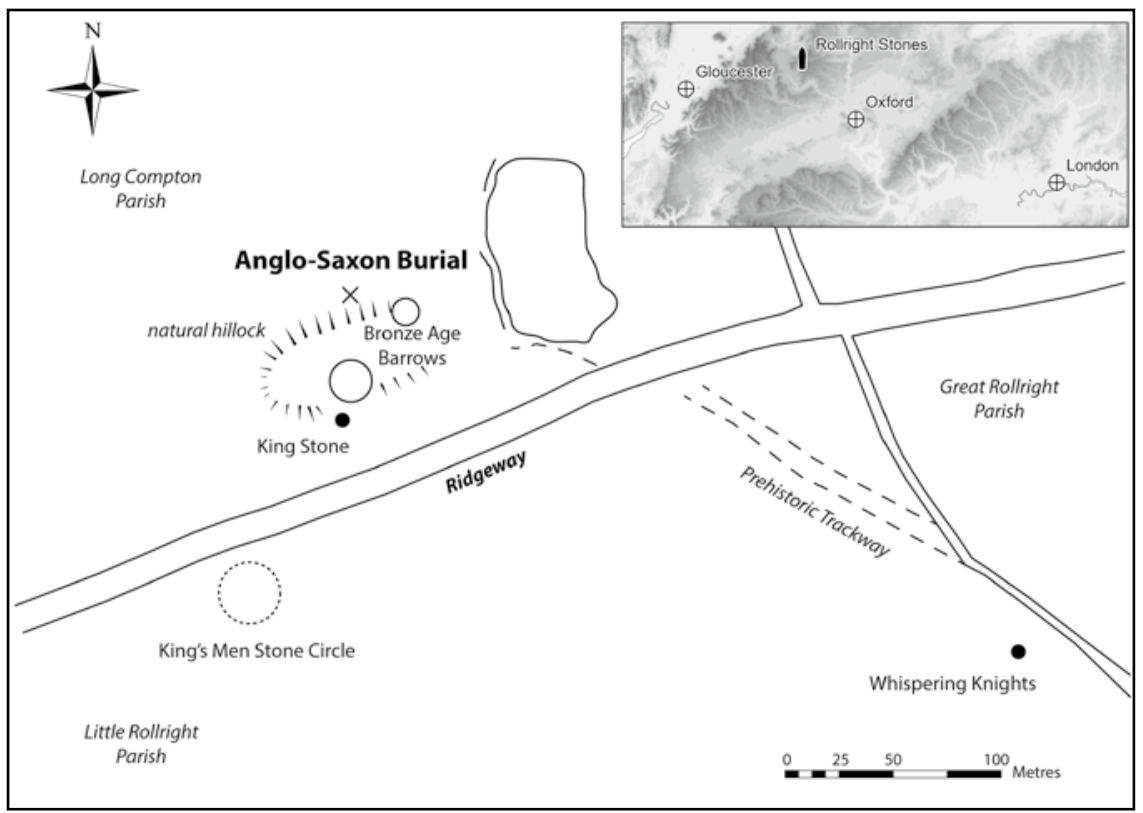

FIGURE 11.6 The Rollright stones showing the King Stone, Ridgeway, and the three-way junction of the Little Rollright, Great Rollright and Long Compton parish boundaries

To answer this question, the wider archaeological context of the burial must first be considered. The Rollright Stones complex includes—in addition to the King Stone-a series of funerary, ceremonial and other monuments spanning several millennia (Fig. 11.6). There is some evidence of late Mesolithic activity, but the earliest monument is probably the burial chamber known as the Whispering Knights, a portal dolmen tomb possibly dating to $c .3800$ BC. Due West of this and probably erected over a millennium later, is the stone circle known as the King's Men, set almost on the crest of the ridge. These monuments attracted several burial mounds in the Bronze Age, including a chambered round cairn occupying the apex of a natural hillock resembling - and for some years believed to be-a Neolithic long barrow. It is possible that the King Stone was erected in the Bronze Age as a permanent marker for the cemetery, but this has not been demonstrated by excavation. In later prehistory, the area became farmland: there are traces of a later Bronze Age or early Iron Age field boundary and a North-South trackway, partly fossilized as the parish boundary

Anglo-Saxon World, ed. M. Clegg Hyer and Gale Owen-Crocker (Liverpool, 2015), pp. $137-61$. 
between Great and Little Rollright. Around 200-50 BC, a middle Iron Age enclosure with a rock-cut ditch was established on the line of the trackway, on the North side of the ridge. The fields around the Stones were cultivated in the Roman period and a few sherds of Roman pottery from the stone circle suggest that it was visited during this period. ${ }^{24}$

The site thus has a complex biography and saw repeated reuse over several millennia. It lies, furthermore, near the junction of what became three parishes (those of Little Rollright, Great Rollright and Long Compton) and near a crossroads, where the major route running from Oxford to Stratford (now marked by a minor road) crosses the Cotswold Ridgeway, which here formed part of a medieval Saltway. To quote Sarah Semple: 'These features give the site the degree of complexity found at the prehistoric ceremonial complexes in Ireland such as Tara, a complexity which prompted their continuation into the early medieval period as locations of ceremony and gathering. ${ }^{25}$ The possibility that the Rollright complex served as a place of assembly in the early Middle Ages is considered below.

While the location of the Rollright burial is indeed striking, prominent locations near boundaries and long-distance routeways are in fact typical of wellfurnished 7 th-century barrow burials — both male and female—as Shepherd's seminal study demonstrated many years ago. ${ }^{26}$ No evidence of a ring ditch was identified at Rollright, although only a small area was exposed around the burial and the evidence is inconclusive; even fairly large Anglo-Saxon barrows do not always produce substantial ring ditches and traces of a shallow ditch could easily have been ploughed away. ${ }^{27}$ It should also be noted that, while the grave's location on the scarp of the Cotswolds-literally 'on the edge' - provides impressive views to the north and west towards the territory of the Hwicce (Fig. 11.7), a barrow located here would not have been easily visible from afar. A traveller walking along the Ridgeway would have encountered such a barrowand the King Stone-relatively suddenly.

24 Lambrick, The Rollright Stones. I am very grateful to George Lambrick for his comments and observations on the prehistoric sequence.

25 Sarah Semple, "Locations of Assembly in Early Anglo-Saxon England," in Assembly Places and Practices in Medieval Europe, ed. Aliki Pantos and Sarah Semple (Dublin, 2004), pp. $135-54$.

26 J. Shephard, "The Social Identity of the Individual in Isolated Barrows and Barrow Cemeteries in Anglo-Saxon England," in Space, Hierarchy and Society. Interdisciplinary Studies in Social Area Analysis, ed. B. Burnham and J. Kingsbury, BAR Int. Ser. 59 (Oxford, 1979), pp. $47-79$.

27 A magnetometry survey conducted in the 1980s identified several "small isolated anomalies" but did not identify a ring ditch in this area. It is intended that a higher resolution survey will be conducted in the future. Lambrick, The Rollright Stones, pp. $57-58$. 


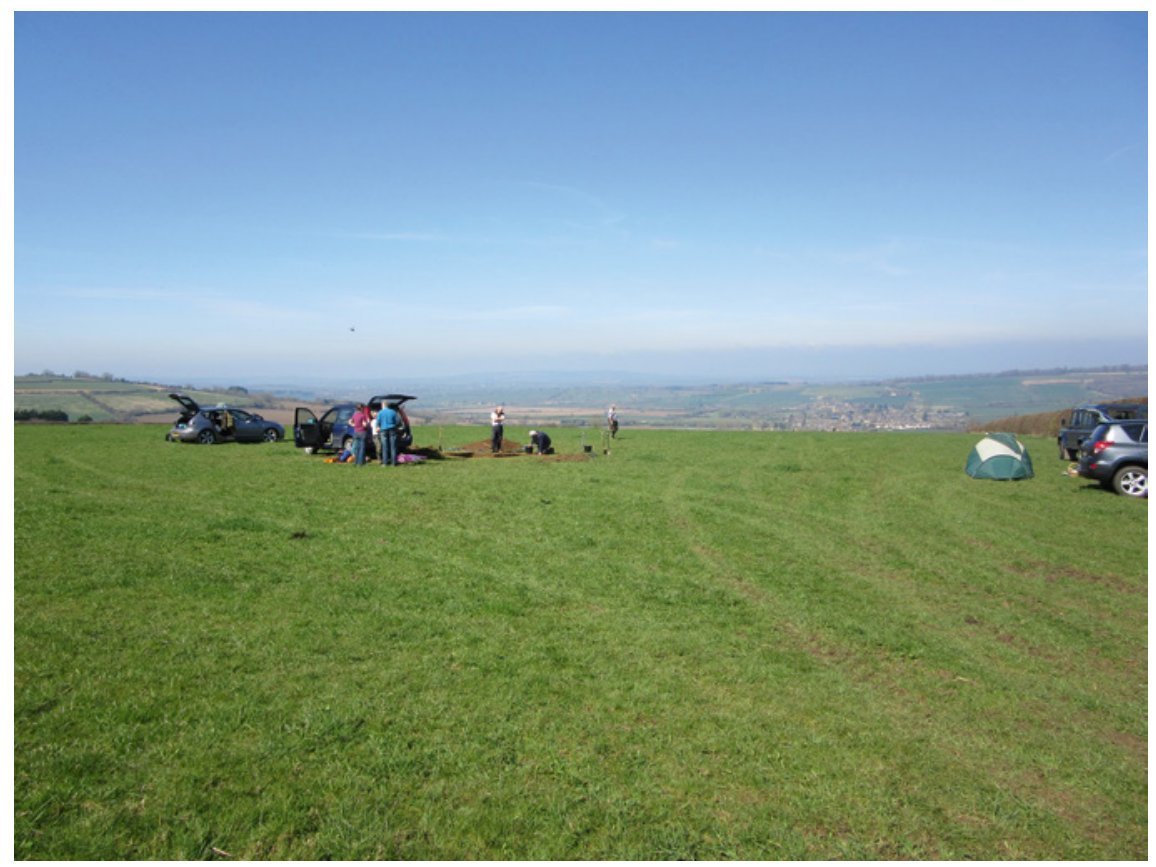

FIGURE 11.7 The Rollright Stones burial under excavation

(C) P. BоOTH

Antiquarian finds from the mid-19th century published by Thomas Beesley demonstrate the existence of early Anglo-Saxon burials - at least thirteen inhumations and one cremation-in the vicinity of the Rollright Stones. Their precise locations are unknown, but they were found during quarrying in fields to the east of the King Stone, on both sides of the Ridgeway and on all sides of what became the three-way junction of the Little Rollright, Great Rollright and Long Compton parish boundaries (Fig. 11.6). ${ }^{28}$ In 2015 , two gilded cast saucer brooches with devolved Style I decoration dating to the first half of the 6th century were uncovered by metaldetector users from the field to the East of the King Stone (PAS nos. SUR${ }_{1 \mathrm{CB}} 11 \mathrm{~A}$; SURC-1C82C9). They appear to form a pair and are likely to come from a single female inhumation. To judge from the sketches and descriptions published by Beesley, none of the antiquarian finds appears likely to date to the

28 Thomas Beesley, "The Rollright Stones," Transactions of the North Oxfordshire Archaeological Society 1 (1856), 61-73. Meaney records the finds from the burials as being housed in the British Museum, but the latter does not now have these in its collections. Audrey Meaney, A Gazetteer of Early Anglo-Saxon Burial Sites (Oxford 1964), p. 260; S. Brunning, pers. comm. 2017 . 
7th century. It is therefore possible that the burial excavated in 2015 was either isolated, or part of a small group of 7 th-century burials inserted into or placed near an earlier burial ground, creating what Semple and Williams have called an 'ancestral palimpsest' ${ }^{29}$

Little can be said with certainty about the site during the Mid and Late Saxon periods. Despite metal-detecting in the area around the Rollright Stones, no Mid or Late Saxon metalwork or coinage has been reported at the time of writing. It is most unlikely, however, that the site's significance was forgotten. Aliki Pantos has demonstrated that Late Saxon open-air assembly sites favoured certain locations, namely near standing stones, mounds, crossroads and along important routeways..$^{30}$ Exceptionally, the location of the Rollright complex (and of the Anglo-Saxon burial) displays all of these characteristics, making it an obvious candidate for a late Saxon assembly site. This was the kind of location where the hundred would meet, where a market would be held, and where royal agents would deal with administrative and legal matters. That said, no documentary or place-name evidence can be identified to support this suggestion, which must, for the time being, remain conjectural. ${ }^{31}$

A well-known piece of local folklore, however, may hint at the later history of the site. It was first recorded in full in the 18th century, although it was already mentioned by Camden in the late 16 th. ${ }^{32}$ It connects the name of the King Stone to a legend involving witchcraft and a thwarted claim to land and power. The legend relates how a knight travelling through the area with his men encountered a witch who tells him that if he can see the village of Long Compton from Little Rollright, he will become King of England. As he steps forward to look, a long hill or mound-presumably the natural hillock with its Bronze Age burial mound described above-rises up before him and blocks his view. The witch then turns him and his knights to stone. The following extract comes from the 18th-century version of the legend as transcribed by Leslie Grinsell:

29 Semple and Williams, "Landmarks for the dead," p. 142.

$30 \quad$ Aliki Pantos, "The Location and Form of Anglo-Saxon Assembly Places: Some 'Moot Points," in Assembly Places and Practices in Medieval Europe, ed. Pantos and Semple, pp. ${ }^{155}-80$. This pattern has been confirmed more recently by work undertaken as part of the Landscapes of Governance project; see, for example, John Baker and Stuart Brookes, "Monumentalising the Political Landscape: A Special Class of Anglo-Saxon Assembly Site," AntJ 93 (2013), 147-62.

31 While several field names appear to reference burial mounds (e.g. trembergh, i.e. "three barrows"), none is in itself suggestive of an assembly site, Lambrick, The Rollright Stones, p. 24.

32 L.V. Grinsell, The Rollright Stones and Their Folklore (St Peter Port, 1977). The intriguing link between this legend and the prehistoric landscape was first noted by Sarah Semple, "Locations of Assembly," p. 149. 
"Seven long strides shalt thou take, and

If Long Compton thou canst see, King of England thou shalt be."

.... As he took his seventh stride forward, there rose before him a long hillock which prevented him from seeing Long Compton. The witch then said,

"As Long Compton thou canst not see,

King of England thou shalt not be.

Rise up, stick, and stand still, stone,

For King of England thou shalt be none;

Thou and thy men hoar stones shall be

And I myself an eldern tree." 33

The legend is probably late medieval in origin, but it is possible that the King Stone acquired its name at a much earlier date. A number of clearly important stones are mentioned in the boundary clauses of late Saxon charters, some of which may have been monuments - in some cases stone crosses-newly erected in the 1oth or 11th century. ${ }^{34}$ Alex Langlands has pointed out that they are typically located at the convergence of important trade routes and at crossroads, such as the kinges stane located north of Winchester referred to by Lantfred and Wulfstan, and mentioned in the boundary clause of the Headbourne Worthy charter. ${ }^{35}$ The location of the 'King Stone' at Rollright displays all the characteristics typical of an early medieval royal stone, raising the possibility that it acquired the name and status of a 'King's Stone' in the Late Saxon period. If so, the legend could have developed in the later Middle Ages to explain why this ancient stone was known as the 'King Stone', centuries after the true origins of its name had been forgotten.

While much more will doubtless be revealed about this intriguing burial following conservation of the finds and analysis of the skeleton, it is already apparent that the grave was carefully positioned within a supernaturally charged 'topography of power'. In a general sense, the ostentatious burial of ancestors reflected the efforts of a new hereditary aristocracy to establish its position within recently formed and rapidly expanding kingdoms. ${ }^{36}$ More specifically, such burials testify to a change in the role of females within these

33 Grinsell, Rollright Stones. 10-11.

34 Andrew Reynolds and Alexander Langlands, "Travel as Communication: A Consideration of Overland Journeys in Anglo-Saxon England," World Archaeology 43:3 (2011), 410-27, at pp. 420-23.

36 Hines and Bayliss, Anglo-Saxon Graves and Grave-Goods. 
land-controlling families. ${ }^{37}$ It is well known that the Conversion period was a time when women - above all royal women - were exceptionally prominent in the English Church. Bede's account of the activities of royal abbesses such as St Hilda clearly indicates that females played a special role in establishing and mediating their family's relationship with the supernatural during the 7 th and 8th centuries. ${ }^{38}$ In the case of the Rollright burial, that special role is signalled by amuletic objects, but also by the skillet/trulleum with its ritual, and perhaps religious, associations. It is probably not a coincidence that the distribution of these well-furnished female burials broadly mirrors that of double monasteries, family institutions governed by women. Both are concentrated mostly in Kent, East Anglia, Northumbria, and along the Thames valley, and both can be seen as strategies deployed by leading families to legitimize and protect newly gained and precariously held land. ${ }^{39}$

Placing the burials of female ancestors at key places in the landscape, for example at or near the boundaries of patrimonial land, thus seems to have been a means of securing tenurial rights by investing landscapesoften already permeated with ancient monuments, as at Rollright-with ancestral associations and family memory. Here it is worth bringing in relevant Irish parallels. A seminal paper published by Thomas Charles-Edwards on 'Boundaries in Irish Law' drew attention to the use of burial mounds (ferta) to mark territorial boundaries in early medieval Ireland. ${ }^{40} \mathrm{~A}$ legal tract of the late 6 th or early 7 th century indicates that such ancestral burials acted in effect as guardians of a family's property. Thus, if someone wished to make a claim to land occupied by another, the following legal process had to be observed: "the claimant takes two yoked horses across the boundary in the presence of one witness. The boundary is marked by a fert, a grave-mound, or a ... collection of grave-mounds .... As the claimant enters the land he must take his horses over a

37 Hamerow, "Furnished Female Burial."

38 Bede, $H E$, especially Book IV; Barbara Yorke, "The Weight of Necklaces': Some Insights into the Wearing of Women's Jewellery from Middle Saxon Written Sources," in Studies in Early Anglo-Saxon Art and Archaeology: Papers in Honour of Martin G. Welch, ed. Stuart Brookes, Sue Harrington and Andrew Reynolds, BAR Brit. Ser. 527 (Oxford 2011), pp. 106-11.

39 Hamerow, "Furnished Female Burial." The importance of women in forming exogamous marriage alliances between leading families is famously reflected in Beowulf (lines 2020-68), in the marriage of Freawaru, daughter of the King of the Danes, to Ingeld, King of the Heathobards. Isotopic analysis of the skeleton may help establish whether the woman buried at Rollright was local, or whether her burial provides evidence of such exogamy. and Change, ed. Peter Sawyer (London 1976), pp. 83-87. 
grave-mound ... He then withdraws and awaits a response from the occupant who is allowed five days to accept arbitration ..." ${ }^{\text {"1 }}$

More recently, Elizabeth O'Brien and Edel Bhreathnach have drawn attention to the archaeological evidence for this practice. ${ }^{42}$ They note that ferta often reused, or were sited near, prehistoric monuments. They were, furthermore, "located in prominent positions, overlooking or close to natural boundaries...." Most of the burials associated with the ferta are female. ${ }^{43}$ One example is linked to a legend about a claim to land that bears a striking resemblance to the Rollright story. It relates to a multi-period ferta site at Ballymacaward in Co. Donegal, at the mouth of the River Erne, where four female burials of 5 th- or 6 th-century date were inserted into a Bronze Age cairn, followed by a further nine, probably Christian, female burials in the 6th or 7 th century. References in the Lives of Patrick-in particular the Vita Tripartita-make it clear that the site lay in "an important border territory" and was much fought over. ${ }^{44}$ One contender persuaded a follower to try and expel Patrick "by promising him all the land he could see" north of a particular hill, probably to be identified with Sheegy's Hill, on which a standing stone is located. When the follower tried to do so, his view was blocked "by a dark cloud that closed round him and restricted his claim." ${ }^{45}$ Like such legends, the richly furnished female burials of 7th-century England, such as the one at Rollright, may have as much to do with the politics of land tenure as with religion and myth.

41 Charles-Edwards, "Boundaries in Irish Law," p. 83-84.

42 Elizabeth O'Brien and Edel Bhreathnach, "Irish Boundary Ferta, Their Physical Manifestation and Historical Context," in TOME: Studies in Medieval Celtic History and Law, ed. Fiona Edmonds and P. Russell (Woodbridge, 2011), pp. 53-64. See also Elizabeth O'Brien, "Pagan or Christian? Burial in Ireland During the Fifth to Eighth Centuries AD," in The Archaeology of the Early Medieval Celtic Churches, ed. Nancy Edwards (Leeds, 2009), pp. $135-54$.

43 O'Brien and Bhreathnach, "Irish Boundary Ferta," p. 55. O'Brien notes that a list of "buried women" in the the Middle Irish topographical lore known as Dindschenchas "associates the names of various burial mounds or ferta with the names of women who are purported to have been buried in these mounds...." (O’Brien "Pagan or Christian?" p. 145).

44 O'Brien and Bhreathnach, "Irish Boundary Ferta," p. 6 o.

45 Bethu Phátraic. The Tripartite Life of Patrick, ed. and trans. Kathleen Mulchrone (Dublin and London 1939), p. 9o. Intriguingly, the site at Ballymacaward lies near a lough whose name means "the lake of the otherworldly women." O'Brien and Bhreathnach, "Irish Boundary Ferta," p. 6 o. 